\title{
Os impactos da Revolução Russa no marxismo de J. C. Mariátegui
}

Jórissa Danilla Nascimento Aguiar

Resumo: O afã revolucionário decorrente da Revolução de 1917 foi determinante para o desenvolvimento marxista de Mariátegui. Discute-se a compatibilidade entre teoria e práxis do autor peruano e sua forma de "territorializar" o marxismo, adaptando a análise materialista histórica às condições concretas e especificidades latino-americanas. Conclui-se indicando como a análise dialética do nacional com o plano internacional e o destaque conferido às experiências de autoorganização locais lhe pareciam fundamentais para tecer uma práxis revolucionária.

Palavras-chave: Revolução Russa. Marxismo. América Latina.

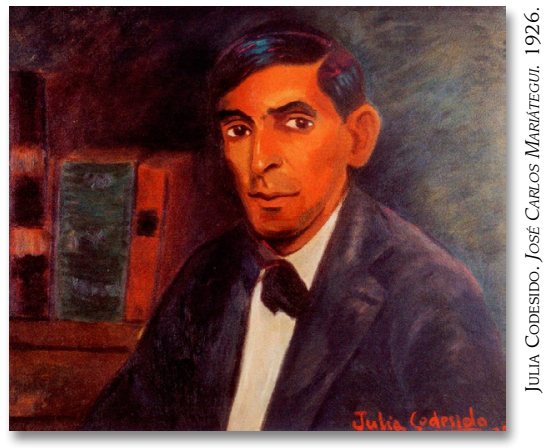

\section{The Russian Revolution impacts on J.C. Mariategui's marxismo}

Abstract: The revolutionary movement from the Revolution of 1917 was decisive for the Marxist development of Mariátegui. It discusses the compatibility between theory and praxis of the Peruvian author and his way of "territorializing" Marxism, adapting the historical materialist analysis to concrete conditions and Latin American specificities. It concludes by indicating how the dialectical analysis of the national with the international

Jórissa Danilla Nascimento Aguiar plan and the emphasis given to the experiences of local self-organization

Doutora em Ciências Sociais (PPGCS - UFCG). Professora de Sociologia da UFCG. Pesquisadora do Grupo de Estudos e Pesquisas PRÁXIS: Estado e Luta de Casses na América Latina (UFCG/CNPq).

E-mail: jdanillaaguiar@hotmail.com. seemed to them fundamental to weave a revolutionary praxis.

Keywords: Russian Revolution. Marxism. Latin America. 


\section{INTRODUÇÃO}

No ano em que se homenageia o centenário da Revolução Russa, se faz necessário debater a atualidade da estratégia revolucionária bolchevique - uma estratégia da tomada do poder pela classe operária a partir de possibilidades abertas pela crise política e econômica vivida durante a I Guerra Mundial - assim como a forma que os marxistas revolucionários se utilizaram, à época, dessa experiência de auto-organização como grande escola política. Mais ainda, a Revolução Bolchevique, como acertadamente indicou o italiano Antonio Gramsci, representou uma "nova atmosfera moral" de liberdade, um fato político fruto da vontade coletiva que o gestou (GRAMSCI, 2004). Seus aspectos centrais de caráter universal abriram espaço para provocar internacionalmente alicerces para pensar uma nova cultura e experiência revolucionária proletária, a partir do que aconteceu na Rússia, fundamentalmente entre 1917 e 1920, inspirando outros revolucionários em todo o mundo, inclusive na América Latina. ${ }^{1}$

Este trabalho objetiva destacar afinidades entre pensamento e práxis política do peruano José Carlos Mariátegui, firmadas no afã revolucionário decorrente de 1917, considerado como profundamente relevante para o desenvolvimento teórico-marxista do autor. Influenciado pelo bolchevismo, Mariátegui vislumbrava na educação das massas - numa concepção mais ampla de educação e formação cultural dos grupos subalternos - uma ferramenta de um projeto político que culminaria na construção do partido revolucionário sob a hegemonia proletária, sendo marcante a experiência ordinovista ${ }^{2}$ na aprendizagem e adesão ao socialismo, durante sua trajetória e estadia na Europa.

A ideia de fomentar o terreno cultural proletário, numa concepção gramsciana, se referenciaria à organização e à disciplina, assim como conquista de consciência do seu próprio papel histórico. A

1 Para atender aos objetivos desse artigo e pela delimitação de espaço, foca-se no impacto da experiência revolucionária russa no desenvolvimento teórico e nas posições políticas do peruano J. C. Mariátegui.

2 Em referência ao periódico italiano dirigido por Gramsci, a experiência ordinovista aqui retratada dimensiona os diversos momentos do L'Ordine Nuovo, ou seja, o movimento de revista de cultura operária até o terreno em que se criaram as premissas para o desenvolvimento de um partido da mesma classe. 
função da educação e a definição de um programa político são as preocupações que se encontram presentes no programa de L'Ordine Nuovo, antes tido como um periódico semanal e que passou a ser um programa de partido que muito influenciou as ideias do revolucionário peruano enquanto vivia na Itália.

A partir das iniciativas educativas e culturais do jovem Gramsci, com a crítica à cultura liberal italiana e à educação enciclopedista como resposta à crise do racionalismo exposta no pós-guerra, fomenta-se a proposta de atuação de L'Ordine Nuovo junto aos conselhos de fábrica como espaços de educação autogestionária. Como destacado por Fernanda Beigel (2005), essas marcas do periodismo desenvolvido em Turim, sob a direção de Gramsci como uma "concepção política e uma forma de práxis", também se fizeram presentes na formação mariateguista, tanto que o marxista peruano funda, ao voltar ao país, uma revista, a Amauta, com finalidade semelhante ao primeiro período ordinovista. ${ }^{3}$

A revista Amauta durou de setembro de 1926 a setembro de 1932, continuando a circular no Peru mesmo após a morte de Mariátegui, seu idealizador. Ela tem seu papel destacado por Alberto Flores Galindo na emblemática afirmação de que a "Amauta acabou sendo mais que uma revista: foi a antessala do partido" (FLORES GALINDO, 1980, p. 69). Pelas páginas dessa revista, passaram escritos de autores peruanos, latino-americanos e também textos de Rosa Luxemburgo, Lênin, Trotsky, André Breton, Máximo Gorki, Marinetti, Georges Sorel, dentre outros. Nela, publicavamse os mais diversos temas como poesia, teatro, crítica literária, linguística, arte, antropologia, relações internacionais, imperialismo, problemas mundiais, política, história, economia, movimento operário e questão indígena, postulando a necessidade objetiva e subjetiva dos grupos subalternos peruanos de conhecer o que ocorre no mundo em termos de política, economia e sociedade. A situação local/nacional não poderia ser compreendida sem uma análise do desenvolvimento capitalista internacional. O processo educativo das massas, numa concepção bem abrangente, assim

3 Amauta, em quéchua, significa pensador, mestre, sábio e se tornou o apelido de Mariátegui. 
como foi preocupação de Gramsci, permeou boa parte das obras de Mariátegui, que chegou a desenvolver teorias sobre a educação das massas indígenas no Peru (MARIÁTEGUI, 1970; 2008; PERICÁS, 2006).

Investiga-se, pois, a influência desse contato vivente com o pensamento marxista e leninista na Europa e o significado da Revolução Russa na interpretação do marxismo de Mariátegui, que reflete no debate marxista latino-americano e mundial em meados da década de 1920 e 1930, partindo do pressuposto de que o autor expressa a ala revolucionária do marxismo frente às variantes reformistas de seus interlocutores, à época.

Indica-se, nos apontamentos conclusivos, como a análise dialética da dimensão nacional com o plano internacional e o destaque conferido às experiências de auto-organização locais lhe pareciam fundamentais para tecer uma práxis revolucionária. É um debate que tem estreita relação com as etapas de expansão do marxismo na América Latina, com o surgimento e com a ampliação da corrente comunista no subcontinente. Relaciona-se também com o tempo presente de avanços de crises políticas, econômicas e de hegemonia, de caráter orgânico, que se expressam em crescentes ataques à classe trabalhadora ao passo que se perde a centralidade da estratégia revolucionária em nome da tática democrática. São discussões que estiveram postas pela esquerda marxista desde 1899, com a publicação do livro de Rosa Luxemburgo intitulado Reforma ou Revolução. A autora realizou uma crítica precisa das bases teóricas e práticas do reformismo, passando pelos debates entre bolcheviques e mencheviques no seio revolucionário, que proporcionaram a emergência da Revolução Russa e que também se faz presente nos debates latino-americanos, a partir do começo da vida republicana até os dias de hoje.

Mesmo fazendo uso da análise da situação concreta do Peru, Mariátegui via na Revolução Russa a mais alta experiência de avanço revolucionário conquistado pelo proletariado mundial, um "tema de estudo geral" para "todos os homens com alguma curiosidade intelectual" (MARIÁTEGUI, 2012, p. 55 - 56), para além dos partidários e propagandistas, por se tratar de um acontecimento de importante magnitude, que não impactaria apenas a Europa. 


\section{PERIODISMO, EDUCAÇÃO E EXPERIÊNCIAS DE AUTO- ORGANIZAÇÃO}

É relevante destacar que, muito embora a principal obra de Mariátegui, Sete ensaios de interpretação da realidade peruana, tenha sido escrita cerca de uma década após a Revolução Russa, em 1928, as inquietações encontradas em seus escritos e sua militância mantêm uma linearidade e consequente maturação, sendo possível verificar que o autor, ao passo que discute fundamentalmente temas nacionais, não perde seu grande norte, que é a construção de uma nova sociedade, articulando teoria e prática revolucionária. Assim, o vivo testemunho histórico é o terreno em que se desenvolve a sua convicção no marxismo.

Mariátegui, ainda em sua juventude, se envolve com o movimento estudantil peruano, inspirado em grande medida pela Reforma Universitária de Córdoba, na Argentina. O movimento estudantil que se iniciou em 1918, com a luta dos estudantes de Córdoba pela reforma da universidade, assinala o nascimento de uma nova geração latino-americana, proporcionando uma agitação posterior em outros países. Não se tratando de um movimento restrito à universidade, partindo da ideologia e inspiração revolucionária da Revolução Russa, a greve geral iniciada pelos estudantes da cidade argentina de Córdoba contra a aristocracia local continha fundamentalmente três reivindicações: a participação dos estudantes no governo das universidades, a inserção dos povos latino-americanos e de sua história na mesma e a modernização do sistema universitário, em que o corpo docente não tinha representação, não se renovava e carecia de liberdade de cátedra (MANIFIESTO..., 1918). Partia-se, então, do conhecimento da realidade local e regional, para se construir, a partir de um vínculo dialético, uma filosofia capaz de oferecer-se como arma intelectual ao proletariado. Falava-se numa reforma que perpassasse pelo âmbito da filosofia, porque, precisamente nessas classes médias, se encontraria a conexão com seu papel na história, conforme afirmava Marx na Crítica à filosofia do direito de Hegel. A filosofia encontraria no proletariado suas armas materiais, enquanto o proletariado encontraria na filosofia suas armas intelectuais (MARX, [1843] 2005, p. 156). 
A militância de Mariátegui - mesmo que ainda incipiente - e a consequente oposição ao então presidente peruano, o general Augusto Leguía, ocasionam o fechamento do jornal onde trabalhava à época, o La Razón, e um "exílio" forçado na Europa, onde viveu de 1919 a 1923, tendo passado a maior parte do tempo na Itália. Vivia como uma espécie de "agente de propaganda do governo no exterior", alternativa que lhe foi dada para não ser preso em solo peruano. Posteriormente, afirmava que somente durante sua estadia na Europa, mais precisamente através da sua experiência de viver por vários anos na Itália e através da passagem por outros países onde vivenciou as experiências do movimento operário nas organizações sindicais e partidárias e os impactos da Revolução Russa, foi capaz de compreender as relações capitalistas em países semicoloniais como no Peru.

Durante a estadia na Europa, Mariátegui é leitor do jovem Gramsci, que estava organizando a imprensa do partido comunista da Itália. As semelhanças entre os dois autores, mesmo não havendo registros de que tenham se conhecido, são inegáveis. Muito provavelmente, tal semelhança é proveniente do espírito revolucionário de ambos, da experimentação do contexto da história italiana, das lutas de classe mundiais (ainda sob o impacto da Revolução de Outubro), do legado dos conselhos e das ocupações de fábricas em Turim, do Biennio Rosso (entre os anos 1919 e 1920), da fundação do Partido Comunista da Itália em 1921, da ascensão do fascismo, assim como dos debates no interior da III Internacional.

Perante a nova configuração mundial de forças e os conflitos no interior do movimento comunista internacional, o marxista peruano participa do Congresso de Livorno e da fundação do Partido Comunista da Itália (PCI), em 1921, assim como da Conferência Econômica Internacional, em 1922, aprofundando-se no debate sobre os sindicatos e a constituição do partido e dos conselhos de fábrica como instrumentos necessários para um processo revolucionário, para a construção de uma nova hegemonia (DIAS, 2000).

O revolucionário peruano pensa a questão da hegemonia desde uma perspectiva leninista e gramsciana, incluindo, no seu programa político, reivindicações que contemplem outras categorias de trabalhadores e conquistando, desta forma, o apoio das classes aliadas. 
Ele postula as necessidades materiais e simbólicas de uma revolução autóctone, a partir do estudo da questão indígena desde a própria perspectiva nativa - uma atividade que empreende no seu livro mais difundido. Os povos autóctones são frações de trabalhadores que devem escrever sua própria história e, para isso, devem se preparar intelectualmente. Essa história integral - utilizando novamente uma categoria apresentada por Gramsci nos Quaderni - deve ser escrita pelos seus próprios intelectuais, de maneira independente das interpretações da historiografia oficial, dominante (GRAMSCI, 2002). A reconstrução da história a partir do índio seria um forte elemento de emancipação, que, junto com o internacionalismo proletário latino-americano, aproximaria esses povos que sentem a subalternidade em uma dupla perspectiva: a exploração econômica pelo trabalho e a opressão social intensificada pelo racismo.

Assimilar as lições dos soviets na Rússia, a fecundidade das experiências nacionais do bolchevismo com as greves de massas que surgiram no contexto pós 1905, como os verdadeiros líderes do movimento revolucionário, a importância dos jornais entre as tendências comunistas significa, para Mariátegui, analisar as experiências concretas de auto-organização e investir na formação política do partido via educação dos trabalhadores. Os soviets russos seriam esse instrumento da educação e sua direção, portanto, deveria estar nas mãos operárias revolucionárias. Os próprios organismos soviéticos, dependendo de quem os dirigia, poderiam levar ao triunfo da Revolução ou ao seu fracasso e o processo revolucionário havia demonstrado que o conselho era o principal organismo da democracia operária, "seriam não apenas a escola de direção e administração do processo fabril, mas também de educação político-cultural da classe operária, dotada de um 'espírito de cisão'." (DEL ROIO, 2006, 314).

Cabe destacar ainda a influência do sindicalista francês Georges Sorel na trajetória de Mariategui. Algumas das incorporações se dão através dos conceitos "espírito de cisão" e, principalmente do "mito revolucionário". Mariátegui visualiza na imaginação libertadora do mito soreliano o que para ele seria a fé revolucionária, para além de um conceito, uma paixão, uma ideia, um sentimento, que 
não significaria, contudo, ingenuidade ou voluntarismo romântico. Segundo Robert Paris (1978), o rompimento com o cientificismo positivista, bem como a recusa da ideia de progresso eurocêntrico que o revolucionário peruano encontrou nas ideias de Sorel, são fundamentais para formar o seu marxismo criativo e heterogêneo. Paris (1978) destaca ainda que, como forma de aderir ao movimento real, Mariátegui se incumbiu da tentativa de unir Lênin e Sorel, fundindo o socialismo científico com a ideia soreliana de mito. ${ }^{4}$ Os exemplos nas conjunturas nacionais podiam ser vistos, na Itália, nos conselhos operários de fábrica, enquanto no Peru, tinham-se os ayllus como experiência auto-organizativa característica da democracia andina. ${ }^{5}$

No horizonte de luta mariateguista, há a reivindicação pela terra, diferentemente da pequena propriedade privada, mas alavancada pela organização coletiva, uma organização que poderia ressurgir do exemplo do coletivismo incaico, uma forma organizativa concreta destacada nos estudos de Mariátegui sobre a formação social e econômica peruana - os ayllus, uma tradição do Peru profundo e das civilizações indígenas pré-colombianas. Na sua obra mais conhecida, os Sete ensaios de interpretação da realidade peruana, o autor indica que esse comunitarismo indígena possui características agrárias em grande medida, como um antecedente de auto-organização. Esse fator natural de socialização da terra presente nos antepassados indígenas atuaria junto

4 Cabendo lembrar que politicamente se distanciava decisivamente do espontaneísmo da ação sindical tomada a cabo por Sorel, a apropriação de categorias sorelianas por Mariátegui se expressa principalmente na utilização da categoria de mito. Para Sorel, o mito seria como o despertar da vontade coletiva, personificado na greve geral e que esta seria gestada nos sindicatos (SOREL, 1992). Em meio ao clima de enrijecimento e burocratização vividos pela social-democracia alemã, as elaborações de Sorel em favor de um sindicalismo revolucionário pautado no mito da greve geral, desde uma perspectiva popular, tomam força na França e influenciam o movimento de massas, chamando atenção também de Gramsci (GALASTRI, 2015).

5 Presentes em todos os Andes da região da América do Sul, os ayllus permanecem como uma experiência auto-organizativa principalmente na Bolívia e no Peru. Andrade (2002), ao descrever a experiência dos ayllus na Bolívia, indica que se tratava de um "sistema de autoridades" que "engloba funções governativas e auxiliares/especializadas" (ANDRADE, 2002, p. 21), lembrando ainda que nesse regime as autoridades são eleitas por sistema rotativo. 
ao enfrentamento do atraso no campo, explicitado na persistência do gamonalismo - prática de latifundiários peruanos que exploravam a força de trabalho do camponês local num regime de servidão -, na associação prematura da oligarquia latifundiária, assim como na nascente associação de uma precária burguesia com o imperialismo.

O líder peruano destaca ainda a necessidade de que essa tradição ayllu mantivesse contato também com o movimento sindical político organizado já existente na capital, Lima, como forma de trazer unidade à classe subalterna. Há ainda que determinar a direção dessa classe ao proletariado que, para o revolucionário peruano, seria o sujeito político capaz de cumprir essa missão e que, durante parte do tempo, principalmente em países de desenvolvimento tardio, exerceria uma combinação de trabalho proletário e também agrícola.

Ao propor soluções concretas para tais entraves, determina que algumas tarefas deveriam ser cumpridas para que se pudesse iniciar uma organização dos grupos da classe trabalhadora peruana, em sua maioria indígenas e camponeses. É importante ressaltar que Mariátegui não acreditava em uma "etapa democrático-burguesa nacional e antifeudal", seu horizonte era o socialismo, que tinha como ponto de partida o Peru incaico e suas formas antecedentes de auto-organização. Essa organização partiria e seria dirigida pelas frações dos próprios grupos subalternos e assim defendia, por essa via, uma nova organização ayllu que havia sido impedida pelo gamonalismo alinhado com a dominação imperialista no subcontinente (MARIÁTEGUI, 2008).

A união da consciência étnica com a consciência classista se faz fundamental para trazer o índio à luta revolucionária, junto com a classe trabalhadora em um sentido mais geral, para que se torne possível a libertação do capitalismo e se reconheça sua capacidade de autogestão econômica, política e cultural. Por não ser proletariado, esquece-se que o índio é também explorado e que seu problema não está restrito ao aspecto cultural ou ao aspecto racial como costumeiramente se aponta, mas está muito mais relacionado ao problema da terra, da sua deposição e ausência de 
uma forma de sustento, no marco do desenvolvimento do sistema capitalista.

As propostas concretas para essa superação da condição subalterna estariam diretamente atadas à formação de uma vanguarda operária, preocupação latente com a prática política e intelectual das massas indígenas, camponesas, de trabalhadores e de estudantes.

Cabe destaque ainda para outro tema relacionado à educação e que faz parte da trajetória do peruano: a participação no projeto das Universidades Populares González Prada ${ }^{6}$ (doravante UPGP), criado em janeiro de 1921 pelo seu principal interlocutor à época, o também peruano e líder Haya de la Torre, sobre o qual se discorrerá no tópico seguinte. Ao voltar da Europa, Mariátegui prontamente aceita o convite para lecionar no UPGP em Lima. O projeto consistia em despertar o interesse pelos estudos nas comunidades organizados coletivamente mediante a realização de cursos de formação política, de análise de conjuntura, tratando-se de uma prática utilizada no subcontinente - principalmente na Argentina e no Chile -, assim como na Europa, visto que o pensamento crítico era tolhido nos espaços de acesso à instrução formal. O peruano enfrenta, como já se podia prever, vários embargos e perseguições do presidente Augusto Leguía, mesmo após seu exílio na Europa, onde se tornou, como gostava de se apresentar, um "marxista convicto e confesso".

\section{A ESTRATÉGIA LENINISTA DE FRENTE ÚNICA}

Dentre os episódios históricos e personalidades políticas fundamentais para a maturidade intelectual e política de Mariátegui, destacam-se os soviets, principal instrumento da frente única política dos operários, e o dirigente revolucionário russo Vladimir Lênin, como grande estrategista. Na perspectiva mariateguista, a palavra de ordem era estabelecer uma aliança e um governo operário-camponês/indígena.

6 Após a realização do primeiro congresso nacional de estudantes peruanos realizados na cidade de Cusco, em 1920, foi aprovada a criação das Universidades Populares González Prada. 
No contexto em que vive e escreve, Mariátegui abraça a característica leninista de "territorializar" o marxismo, adaptando a análise teórica às condições concretas latino-americanas, como a particularidade da opressão pela diferenciação da raça - num sentido político do termo -, sem descurar o caráter revolucionário dessa análise. Utiliza arsenal teórico marxista para atentar para as especificidades das lutas de classe no Peru, centrando forças em entender como o problema da expropriação da terra se alinhava e operava em favor do imperialismo na América Latina, aliado também ao capital estrangeiro, o capital transnacional. Como entraves à emancipação dos povos subalternos peruanos, havia a enorme concentração fundiária e a permanência das relações servis. O objetivo de seu estudo da formação social peruana, portanto, era postular possibilidades de se empreender uma revolução socialista no país. Não menos importante era entender e avançar no combate ao racismo como instrumento de dominação e a particularidade indígena no âmbito da luta de classes, uma questão que o debate marxista lida com alguma dificuldade até os dias de hoje. Trata-se, desta maneira, de um ponto nevrálgico para entender sua obra perceber como Mariátegui analisa a questão das raças na América Latina e como essa problematização se dava no seio do debate marxista no subcontinente, na década de 1930, quando se pontuava a necessidade de superação do colonialismo junto com seu principal interlocutor, o também peruano Haya de la Torre.

Haya de la Torre, que em meados da década de 1920 é também um destacado líder do movimento estudantil peruano e fundador da Aliança Popular Revolucionária, a APRA - uma espécie de frente única anti-imperialista -, realiza uma crítica ao marxismo eurocêntrico e defende uma visão essencialista latino-americana. As posições políticas dos autores partem das referências das versões eurocêntricas do marxismo da II Internacional e da III Internacional que inspiraram a disseminação das ideias marxistas no subcontinente. Löwy (2006) ressalta que "as primeiras tentativas significativas de analisar a realidade latino-americana em termos marxistas e de estabelecer as bases para uma orientação política revolucionária vieram com o surgimento da corrente 
comunista" (LÖWY, 2006, p. 14), uma corrente ainda tímida, que inspirava partidos e teve suas resoluções iniciais pautadas na III Internacional. O nosso "atraso colonial", debatido também durante a III Internacional, respaldou o sentimento anti-imperialista que caracterizou a luta na América Latina em alguns períodos. Assim, destacar as diferenças entre a fração reformista, que acreditava não ter a burguesia esgotado suas funções históricas e a fração revolucionária, que julgava a burguesia incapaz de reconstruir a riqueza social destruída pela guerra, era uma preocupação de Lênin retomada pela Amauta.

Posteriormente, José Carlos Mariátegui, em contraposição a Haya de la Torre, assume um posicionamento distinto em relação às contribuições do marxismo para analisar e modificar a realidade latino-americana. Demonstra que a visão dominante de mundo se impôs entre os processos civilizatórios diversos não só através da presença cultural, mas também através da exploração dos povos nas relações de produção. A evolução do capitalismo e, consequentemente, da economia mundial ordena-se em torno da aceleração na acumulação do capital nos sistemas produtivos e da intensificação do comércio internacional, via expansão da organização social do trabalho e incorporando das demais áreas geográficas à economia. E, desta maneira, a existência de mercados externos cumpriu papel fundamental no processo de acumulação, sendo a América Latina uma peça imprescindível para essa acumulação.

Uma das fulcrais diferenças entre a leitura do marxismo e do anti-imperialismo expostas no pensamento de Mariátegui e Haya de la Torre está no entendimento do último acerca do significado do imperialismo. Haya de la Torre considera que a formulação leninista sobre o imperialismo estava equivocada e este fenômeno não se trataria de uma fase superior do capitalismo e, sim, de uma opção dos governos. Esse era um debate que se colocava no campo do marxismo revolucionário, que cristalizava diferenças políticas e polêmicas com alguns anti-imperialistas, que, como Haya de la Torre, afirmavam que se vivia na América Latina um espaço-tempo diferente do da Europa. Firmava-se, assim, uma visão instrumentalista do Estado, como se o Estado fosse um 
instrumento neutro e que não servisse para legitimar os interesses da classe burguesa. Como consequência política, abandonava-se o marxismo em favor de uma revolução burguesa latino-americana.

É importante ressaltar que Mariátegui - sem cair num romanticismo do qual era criticado, num culturalismo autóctone, tampouco em uma perspectiva eurocentrista - defende a reconstrução peruana sobre a base do índio, sem procurar transplantar modelos de desenvolvimento europeus para o subcontinente:

Os indigenistas revolucionários, em vez de um platônico amor ao passado incaico, manifestam uma ativa e concreta solidariedade com o índio de hoje. Este indigenismo não sonha com utópicas restaurações. Considera o passado como uma raiz, mas não como um programa. Sua concepção da história e de seus fenômenos é realista e moderna. Não ignora nem esquece nenhum dos fatos históricos que, nestes quatro séculos, modificaram, com a realidade do Peru, a realidade do mundo (MARIÁTEGUI, 1925 [tradução livre] apud CARVALHO; AGUIAR, 2013, p. 115).

Também não atribui a alguma burguesia nacional latino-americana a tarefa de uma revolução de qualquer tipo (burguesa ou nacionalista), apoiado nos preceitos marxistas e influenciado pelo debate na época e em consonância com os quatro congressos da Internacional Comunista (IC). Foi exatamente no IV Congresso da IC que foram aprovadas também as Teses gerais sobre a questão do Oriente, que diziam que a frente única proletária seria aplicável aos países imperialistas, enquanto a frente única anti-imperialista seria adequada aos demais. A Amauta se apropriou dinamicamente das táticas de Frente Única Proletária e da Frente Única Antiimperialista e ampliou o alcance da tática frentista para incorporar os indígenas, que, à época, compunham 4/5 dos oprimidos do país.

Mariátegui problematiza que a marginalidade na qual se encontravam os indígenas peruanos não se devia a uma suposta superioridade étnica ou cultural dos brancos, mas a uma dominação política e econômica levada a cabo pelas classes dominantes principalmente pela dominação territorial (MARIÁTEGUI, 2011; 2008). Ele pensa a questão da frente única anti-imperialista, posteriormente, a de classe e o tema da hegemonia, desde uma perspectiva 
leninista e gramsciana, incluindo, no seu programa político, reivindicações que contemplem outras categorias de trabalhadores, conquistando, desta forma, o apoio das classes aliadas. Enxerga como necessário despertar, na classe trabalhadora e fundamentalmente nos grupos historicamente subalternizados no Peru e em grande parte da América Latina - os indígenas -, uma vontade popular em avançar numa revolução socialista internacional, partindo das realidades locais. Mais do que um ajuste na práxis frentista, esta ampliação exige esforços teóricos de compreensão da economia, política e culturas presentes no território peruano.

Como decorrência prática de sua estadia na Europa concentradamente na Itália, ao retornar ao Peru, em 1923, Mariátegui esforçou-se em elaborar o programa e o partido da revolução no país, compreendido como parte da economia mundial. Seu propósito era unir a tarefa de compreender a realidade peruana, contribuir para a organização do proletariado como classe consciente e impulsionar as lutas indígenas e camponesas em unidade com o programa socialista. Restava às classes subalternas - composta em grande parte por indígenas - pensar estrategicamente como poderiam se organizar politicamente para se defender e também para contra-atacar. O proletariado não deveria ser mero espectador das crises capitalistas mundiais. Era fundamental demonstrar através da sua experiência e fontes teóricas que mesmo uma crise que acontecia e tinha seu estopim na Europa, determinaria os rumos do proletariado mundial. Essa era uma necessidade ainda maior entre os intelectuais revolucionários, de vanguarda.

Durante a Revolução Russa, ampliaram-se as alianças entre os impérios e os partidos burgueses; o medo da ameaça soviética desencadeou a luta entre capitalismo e socialismo em todo o mundo, incluindo o subcontinente latino-americano. Mariátegui propunha, já na década de 1930, um marxismo latino-americano concreto dialético, que romperia com o sistema capitalista pela revolução socialista, através da luta de classes, com o índio entendido como parte da frente única de classe. Sua elaboração teórica e seus intentos organizativos, em um "período de enrijecimento do debate político na Internacional Comunista (IC)" (CARVALHO; AGUIAR, 2012, p. 108), buscaram influência no pensamento de 
Lênin e nas discussões do segundo congresso da IC, que pautava a questão colonial e nacional, bem como a necessidade revolucionária de rejeitar as ilusões pequeno-burguesas nacionalistas, sendo marcante o posicionamento leninista da política de frente única de classes, reaproximando classe operária, campesinato e partido, uma composição teórico-política que também inspirou o socialista peruano. Seria a partir dessa aproximação com o marxista russo que Mariátegui declararia que o socialismo no Peru não deveria ser "decalque ou cópia"7 (MARIÁTEGUI, 2011).

\section{O DEBATE SOBRE A ATUALIDADE DA ESTRATÉGIA REVOLUCIONÁRIA E O PENSAMENTO DE MARIÁTEGUI}

Na América Latina, além do combate às incipientes insurreições, tentou-se barrar a evolução de alguma perspectiva teórica que fosse de encontro ao que impunha o capitalismo personificado na Europa, principalmente na Europa Ocidental, como centro de poder e saber mundial. Questões políticas como organização, aliança de classe e o interesse por problemas sociais por parte dos intelectuais da época fizeram com que se falasse na aplicação do pensamento marxista na América Latina. As disputas ideológicas eram latentes também no interior do marxismo, fato que provocou uma ruptura entre Mariátegui e Haya de la Torre.

Em um texto recente em que analisa a leitura de Mariátegui acerca da Revolução Russa, Sydnei Melo (2017) destaca que num:

[...] contexto de fortes disputas ideológicas, que contrapunham críticos e defensores do regime soviético na Europa, nos Estados Unidos e na América Latina, Mariátegui assumiu a postura de divulgação e defesa da URSS, realizando tal tarefa por meio de leituras da conjuntura política internacional e redigindo biografias das principais lideranças políticas russas como George Tchitcherin, Anatóli Lunatcharski, Grigori Zinoviev, Félix Dzerzhinsky, Leonid Krassin, além de Lenin e Leon Trótsky. (MELO, 2017, p. 01)

\footnotetext{
7 "Não queremos, certamente, que o socialismo seja na América decalque e cópia. Deve ser criação heroica. Temos que dar vida, com nossa própria realidade, em nossa própria linguagem, ao socialismo indoamericano. Eis aqui uma missão digna de uma geração nova" (MARIÁTEGUI, 2011, p. 120).
} 
Sobre o debate da Revolução Russa, Melo (2017) destaca que, nos escritos mariateguistas, sempre se pode ver de maneira clara uma defesa do processo histórico e político desencadeado pelos bolcheviques em outubro de 1917. Destacando também as divergências entre diferentes grupos socialistas, a Revolução de Outubro deveria ser a escola para a classe revolucionária.

Entende-se, assim, que Mariátegui procurou traduzir e adaptar métodos leninistas para a América Latina. Desenvolve seus ensaios teóricos e formula sobre qual fração subalterna lideraria uma frente única anti-imperialista e, posteriormente, de classe frente a um processo revolucionário, uma análise que Lênin realizou na Rússia ao concluir que sem o apoio dos camponeses não haveria revolução possível num país com grandes porções de trabalhadores camponeses submetidos à situação de semisservidão.

A partir de uma análise da realidade concreta do Peru da época, Mariátegui descrevia criticamente a situação do país e do subcontinente, apontando, também, soluções para o problema do índio, sem cair no culturalismo como propunha algumas escolas literárias. De fato, pretendia olhar, observar e entender o Peru para então organizar operários, camponeses e indígenas e, depois, formar um partido socialista. Apontava, nos Sete ensaios, que o problema do índio não poderia estar restrito ao aspecto cultural, como hoje algumas correntes - incluindo os autores pós-coloniais - pretendem sublinhar. A subordinação do marxismo a questões éticas e raciais encobre justamente a necessidade de se acabar com essa exploração através da luta política entre classes.

Há menos de duas décadas, o subcontinente latino-americano experimentava um intenso momento de lutas, ilustrando algumas transformações no cenário político regional. O triunfo eleitoral de Hugo Chávez na Venezuela em 1998, o fracasso da Área de Livre Comércio das Américas (ALCA), o projeto de construção da Aliança Bolivariana para os Povos de Nossa América (ALBA), o estopim da crise capitalista em 2008 e as lutas por nacionalizações na Bolívia e no Equador, seguidas pela primeira ascensão presidencial de Evo Morales (2005) e Rafael Correa (2006), respectivamente, sinalizavam mudanças na geopolítica da América Latina. São governos que articularam institucionalidade e pautas 
nacional-populares num projeto de caráter heterogêneo e continental e que reascenderam - ao menos em discurso - na dimensão política uma tentativa de ruptura com as estruturas de poder e cultura antidemocrática que minavam a credibilidade das instituições políticas locais, trazendo a substituição das constituições em vigor e renovação dos quadros políticos dirigentes.

Os governos nacional-populares latino-americanos, na ausência de uma caracterização mais adequada, inauguraram, assim, uma agenda de alternativa política às estruturas de poder vivenciadas desde a terceira onda democrática em meados da década de 1980 e que se instalam no aparelho do Estado. É importante lembrar que, mesmo antes da crise capitalista que eclode no centro imperialista estadunidense em 2008, a América Latina aparecia como um subcontinente em ebulição, onde vários movimentos sociais despontaram na cena política na última década do século passado, tendo como exemplo as pioneiras rebeliões zapatistas em 1994, no México, a atuação dos piqueteros, na Argentina, à mesma época, a resistência dos mapuches no Chile e as inúmeras lutas das nacionalidades no Equador, no Peru e na Bolívia. São movimentos sociais que fundamentalmente retomam as lutas pela autonomia das etnias, pela libertação nacional e, principalmente, pela nacionalização dos recursos naturais (CARVALHO; AGUIAR, 2012).

\section{CONCLUSÕES}

Nosso debate está vinculado à ideia de que a constituição de uma nova sociedade e de um novo homem, como falaria Ernesto "Che" Guevara, pensando uma nova hegemonia em termos gramscianos, implica uma transformação para uma nova estrutura econômica, nova organização política e também nova orientação ideológica e cultural. Essa reflexão recupera uma preocupação já trazida por alguns marxistas latino-americanos que procuravam analisar as especificidades do subcontinente e parte do pressuposto de que um exemplo emblemático é o marxista José Carlos Mariátegui, figura política marcante no debate marxista da década de 1930 e que apresentou consequências para o socialismo mundial. Mariátegui problematizou as particularidades 
latino-americanas, fundamentalmente sobre o problema da raça na América Latina e sobre o desenvolvimento econômico-político dos indígenas, premissa que exigiu esforços teóricos de compreensão da economia, da política e das culturas presentes no território peruano.

A Amauta conferiu destaque à forma de organização política dos soviets, à grande riqueza da experiência popular bolchevique e à universalidade de aspectos centrais da revolução russa como a preocupação com os temas da educação e da cultura, investindo na formação política do partido revolucionário de massas, partindo da observação e da experiência de cada situação concreta. A preocupação era como preparar uma estratégia revolucionária para a vitória dessa frente única, cuja direção estaria nas mãos operárias revolucionárias, a vanguarda mais avançada e temperada nas lutas.

Em meio à autenticidade das interpretações de Mariátegui sobre a realidade peruana e mundial, assim como sobre os possíveis caminhos ao socialismo, destacam-se as relações com o movimento operário mundial, sobretudo nas aproximações com a III Internacional e nas tensões estabelecidas, a partir do processo de stalinização desta organização, assimilando as lições dos soviets - principal instrumento de frente única política dos operários - na Rússia contra os oportunistas. Seriam também os soviets o instrumento de ligação orgânica entre o partido. Não se trata, para o autor peruano, de fetichismo soviético, mas de trazer teoricamente e objetivamente a Revolução Russa e a defesa do bolchevismo em seu plano de ideias e ações.

Importante também para Mariátegui seria a necessidade de o proletariado e os camponeses peruanos e latino-americanos conhecerem a situação mundial, sobretudo por meio de uma imprensa comprometida ideologicamente com as classes populares. Delegava pontual relevância ao fato de grupos socialistas e sindicalistas possuírem seus próprios instrumentos de cultura, de modo a contagiar o povo pelo interesse no estudo.

Frente à nova dinâmica da luta de classes que começa a se desenvolver num contexto de crise capitalista mundial, se faz necessário uma reflexão estratégica apoiada na contribuição de 
autores que alertam sobre a inviabilidade das direções pequeno -burguesas ou a impossibilidade de aliança com frações burguesas no combate ao imperialismo.

Estudar esses processos e trazê-los para o debate contemporâneo permite, entre outros aspectos, analisar criticamente governos cujos discursos nacional-desenvolvimentistas voltaram à cena política, reavivando velhas ilusões, enquanto incontáveis lutas das nacionalidades autóctones defendem o que restou de seus territórios e resistem ao genocídio em alguns países da América Latina.

Seguindo essa reflexão, Mariátegui permanece como leitura necessária em um contexto de persistência de levantes e movimentos indígenas por toda América Latina, cuja vitalidade pode ser vista nas marchas multitudinárias na Bolívia contra a dilaceração do Território Indígena e Parque Nacional Isiboro-Secure (TIPNIS), frente ao avanço do neodesenvolvimentismo, na marcha dos zapatistas, em Chiapas, nos mapuches no Chile, assim como na resistência das inúmeras lutas das nacionalidades originárias que resistem ao genocídio no Equador, no Peru e no Brasil.

\section{REFERÊNCIAS}

ANDRADE, E. de O. A Comuna de La Paz: história da Assembleia Popular de 1971. 2002. 365f. Tese (Doutorado em História) - Departamento de História, Faculdade de Filosofia, Letras e Ciências Humanas, Universidade de São Paulo, São Paulo, 2002.

BEIGEL, F. Una mirada sobre otra: el Gramsci que conoció Mariátegui. Estudos de Sociologia, Araraquara, n. 18-19, p. 23 - 49, 2005.

CARVALHO, S. de; AGUIAR, J. D. N. Mariátegui e as táticas de frente única. Revista Lutas Sociais, São Paulo, v. 17, n. 30, p. 108 - 122, 2013.

DEL ROIO, M. Gramsci e a educação do educador. Cadernos Cedes, Campinas, v. 26, n. 70, p. $311-328,2006$.

DIAS, E. F. Gramsci em Turim. São Paulo: Xamã, 2000.

FLORES GALINDO, A. La agonia de Mariátegui. Lima: DESCO - Centro de Estudios y Promoción del Desarollo, 1980.

GALASTRI, L. Gramsci, marxismo e revisionismo. Campinas: Autores Associados, 2015. 
GRAMSCI. A. Cadernos do Cárcere: O Risorgimento e notas sobre a história da Itália. v. 5. Rio de Janeiro: Civilização Brasileira, 2002.

Escritos Políticos. v. 1. Rio de Janeiro: Civilização Brasileira, 2004.

LÖWY, M. O marxismo na América Latina: uma antologia de 1909 aos dias atuais. 2. ed. São Paulo: Editora Fundação Perseu Abramo, 2006.

MANIFIESTO de la F. U. de Córdoba. [S.l.: s.n.], 1918. Disponível em: $<$ http://www.reformadel18.unc.edu.ar/manifiesto.htm $>$. Acesso em: 12 jun. 2017.

MARIÁTEGUI, J. C. Temas de educación. Lima: Amauta, 1970.

Por um socialismo indo-americano. Rio de Janeiro: Editora da UFRJ, 2011.

Sete ensaios de interpretação da realidade peruana. São Paulo: Expressão Popular, 2008.

Revolução Russa. São Paulo: Expressão Popular, 2012.

MARX, K. Crítica à filosofia do direito de Hegel. Boitempo: São Paulo, 2005.

MELO, S. Mariátegui e a Revolução Russa. Blog Junho, [online], 2017. Disponível em: <http://blogjunho.com.br/mariategui-e-a-revolucaorussa/>. Acesso em: 21 jun. 2017.

PARIS, R. Mariátegui: un sorelismo ambíguo. In: ARICÓ, J. (org.). Mariátegui y los origenes del marxismo latino-americano. México: Cuadernos de Passado y Presente, 1978. p. 145 - 161.

PERICÁS, B. Mariátegui e a questão da educação no Peru. Lua Nova, São Paulo, n. 68, p. 169 - 204, 2006. Disponível em: <http://www.scielo.br/ pdf/ln/n68/a07n68.pdf >. Acesso em: 07 abr. 2017.

SOREL, G. Reflexões sobre a violência. São Paulo: Martins Fontes, 1992. 